\title{
Changes in Optical Coherence Tomography Parameters in Patients with Unilateral Carotid Artery Stenosis
}

\author{
Tek Taraflı Karotis Arter Stenozlu Hastalarda Optik Koherans Tomografi \\ Parametrelerindeki Değişiklikler
}

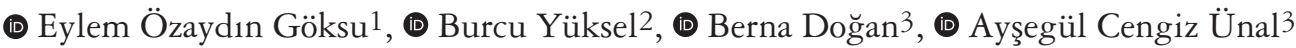 \\ ${ }^{1}$ Antalya Training and Research Hospital, Clinic of Neurology, Antalya, Turkey \\ 2ंistanbul Bakirkoy Prof. Dr. Mazhar Osman Mental Health and Neurological Diseases Training and Research Hospital, Clinic of Neurology \\ and Neuosurgery, Istanbul, Turkey \\ ${ }^{3}$ Antalya Training and Research Hospital, Clinic of Ophtalmology, Antalya, Turkey
}

\begin{abstract}
Objective: The retina layer belongs to the end-stream region of the internal carotid artery, and thus various ophthalmic symptoms can present in patients with carotid artery stenosis. The aim of this study was to examine the changes in retinal nerve fiber layer thickness (RNFLT), central macular thickness (CMT), retinal ganglion cell layer (RGCL), and choroidal thickness (CT) in patients who had unilateral (symptomatic or asymptomatic) carotid artery stenosis (CAS) using optical coherence tomography (OCT).

Materials and Methods: In this prospective observational study, patients with confirmed unilateral CAS (symptomatic or asymptomatic) in computed tomography angiography were recruited. RNFLT, CMT, and RGCL were compared using spectral domain-OCT. CT was analyzed using enhanced depth imagingOCT.

Results: A total of 28 patients with unilateral CAS (17 asymptomatic, 11 symptomatic) were recruited. There were no significant differences between the eye on the stenotic side and the fellow eye according to RNFLT, CMT, RGCL, and CT in the asymptomatic group ( $\mathrm{p}=0.986, \mathrm{p}=0.945$, $\mathrm{p}=0.569$, and $\mathrm{p}=0.796$, respectively). Similarly, in the symptomatic group, no significant differences were found between the eye on the stenotic side and the fellow eye according to the same parameters $(\mathrm{p}=0.693, \mathrm{p}=0.409, \mathrm{p}=0.792$, and $\mathrm{p}=0.597$, respectively). When comparing the eyes on the stenotic sides in both groups, no significant differences were found ( $\mathrm{p}=0.85, \mathrm{p}=0.24, \mathrm{p}=0.7, \mathrm{p}=0.98$ respectively).
\end{abstract}

Conclusion: The decrease in retinal artery blood flow did not lead to morphologic or functional changes of the retina in symptomatic or asymptomatic carotid artery disease.

Keywords: Carotid artery stenosis, OCT, retinal nerve fiber layer thickness, stroke, RNFL

Öz

Amaç: Retina internal karotis arterin kanlandırdığı son akım bölgesidir ve bu nedenle karotis stenozlu hastalarda çeşitli oftalmik semptomlar görülebilir. Bu çalışmanın amacı, tek taraflı karotis arter stenozu olan hastalarda (semptomatik veya asemptomatik), optik koherans tomografi (OCT) ile retinal sinir lifi kalınlığ (RNFLT), santral maküler kalınlık (CMT), retinal ganglion hücre tabakası kalınlığı (RGCL) ve koroidal kalınlık (CT) değişikliklerini saptamaktır.

Gereç ve Yöntem: Bu prospektif gözlemsel çalışmaya, bilgisayarlı tomografi anjiyografi ile doğrulanan tek taraflı karotis arter stenozu olan hastalar (semptomatik veya asemptomatik) dahil edildi. Spektral alan-OCT ile RNFLT, CMT ve RGCL; gelişmiş derinlik görüntüleme-OCT ile CT ölçüldü.

Bulgular: Tek taraflı karotis arter stenozu olan 28 hasta (17 asemptomatik, 11 semptomatik) çalışmaya alındı. Asemptomatik grupta, stenotik taraftaki göz ile diğer göz karşılaştırıldı ̆̆ında, RNFLT, CMT, RGCL ve CT değerleri arasında anlamlı fark saptanmadı (sırasıyla; $p=0,986, p=0,945, p=0,569$, p=0,796). Benzer

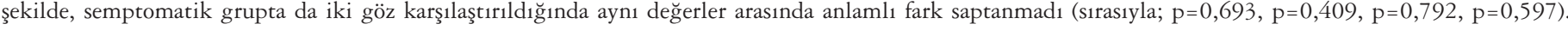
Stenozlu taraflardaki gözler karşılaştıııldı ̆̆ında da aynı değerler için anlamlı fark saptanmadı (sırasıyla; $\mathrm{p}=0,85, \mathrm{p}=0,24, \mathrm{p}=0,7, \mathrm{p}=0,98$ ).

Sonuç: Bu çalışmada, semptomatik ve asemptomatik karotis arter stenozu olan hastalardaki retinal arter kan akımındaki azalma retinada morfolojik ya da fonksiyonel değişikliklere yol açmamıştır.

Anahtar Kelimeler: Karotis arter stenozu, OCT, retina sinir lifi kalınlı̆̆ı, inme, RNFL

Address for Correspondence/Yazışma Adresi: Eylem Özaydin Göksu MD, Antalya Training and Research Hospital, Clinic of Neurology, Antalya, Turkey Phone: +90 5054691758 E-mail: eylemozaydin@hotmail.com ORCID: orcid.org/0000-0001-8851-3094

Received/Geliş Tarihi: 08.10.2020 Accepted/Kabul Tarihi: 07.01.2021

${ }^{\circ}$ Copyright 2021 by Turkish Neurological Society

Turkish Journal of Neurology published by Galenos Publishing House. 


\section{Introduction}

Stroke is the third most common cause of death in most Western countries, after coronary heart disease and cancer (1). A stroke is devastating to health, leading to substantial disability, and leads to labor loss in the population. Eighty percent of stroke is ischemic, and internal carotid artery (ICA) stenosis accounts for $15 \%$ of ischemic stroke subtypes (2). In patients with carotid atherosclerosis, the risk of stroke is altered by the presence of collateral circulation and also altered by the varying demographic properties of the patients. The incidence of stroke in patients with asymptomatic and symptomatic ICA stenosis is reported to be $9 \%$ and $10 \%$, respectively $(3,4,5)$.

Various ophthalmic symptoms can present in patients with carotid artery stenosis (CAS) due to retina belongs to the end-stream region of the ICA. When the ICA is obstructed, such compensation mechanisms occur; collateral circulation from the circle of Willis and collateral channels open up between the terminal external carotid artery (ECA) branches and the terminal branches of the ophthalmic artery. Through these channels, there is retrograde flow via the ophthalmic artery to the ICA. Thus, ophthalmologic symptoms and signs caused by carotid atherosclerotic disease can occur due to retinal emboli arising from the atherosclerotic plaque or hypoperfusion of the retinal and choroid due to the ICA stenosis or opening up of collateral channels causing delay/asymmetry of ECA pulses or ocular ischemic syndrome $[(\mathrm{OIS})]$; venous stasis retinopathy] (6).

Ultimately, histopathologic changes occur depending on the tissue ischemia (7). Previous experimental studies showed that bilateral common carotid artery occlusions might cause incomplete retinal ischemia, which resulted in chronic ganglion cell loss, optic nerve degeneration, and other cerebral degeneration presentations (8).

The early detection of these symptoms and signs caused by carotid atherosclerosis, as well as an understanding of the pathophysiologic changes in the retina and the optic nerve of patients with hemodynamically significant ICA stenosis, might be important for physicians to predict the risk of stroke.

The examination of the retina by optical coherence tomography (OCT), which is a non-invasive technique that uses near-infrared light to generate high-resolution cross-sectional images of the retina, has advantages in showing ischemia (9).

The aim of this study was to examine the changes in retinal nerve fiber layer thickness (RNFLT), central macular thickness (CMT), retinal ganglion cell layer (RGCL), and choroidal thickness (CT) in patients who had unilateral (symptomatic or asymptomatic) CAS confirmed in OCT.

\section{Materials and Methods}

In this prospective observational study, patients with unilateral CAS (symptomatic or asymptomatic) were recruited. The study was approved by the Antalya Training and Research Hospital Ethics Committee (48/2, 16.10.2014) and written informed consent was received from all participants. The study was performed according to the tenets of the Declaration of Helsinki for research involving human subjects.

Twenty-eight patients (11 females and 17 males) with unilateral CAS (symptomatic or asymptomatic) were included. The demographic variables of the participants were recorded.
Computed tomography angiography (CTA) was performed to calculate the degree of CAS ( $\geq 50 \%$ stenosis rate). Patients with asymptomatic CAS were defined as individuals who lacked ischemic symptoms typical for carotid territory in the last 6 months preceding the study recruitment and who had $\geq 50 \%$ stenosis in CTA. The symptomatic CAS group was defined as those who had had a stroke (clinical findings as hemiparesis or amaurosis fugax) depending on carotid artery disease. The eye on the stenotic side was compared with the fellow eye.

All patients underwent a detailed ophthalmic examination that included visual acuity testing, refraction assessment, anterior segment slit-lamp biomicroscopy, fundus examination, and patients who had best-corrected Snellen visual acuity of 20/20 in both eyes were included. All were examined by an ophthalmologist before performing other tests. All visual tests were performed binocularly. RNFLT, CMT, and RGCL were assessed using spectral domain-OCT (Cirrus HD OCT, Carl Zeiss Meditec, Dublin, CA, USA). CT was analyzed using enhanced depth imaging-OCT.

In the symptomatic and asymptomatic CAS groups, the eye at the same side of stenosis and the opposite eye were compared in terms of OCT parameters as RNFLT, CMT, RGCL, and CT. OCT was applied to the symptomatic CAS group within the first week of stroke. The correlation between the CAS rate and OCT parameters was investigated. Patients were excluded if there was (a) bilateral CAS, (b) glaucoma, (c) diabetes mellitus, and (d) longterm hypertension (up to 4 years), (e) atrial fibrillation.

\section{Statistical Analysis}

The study data were analyzed in SPSS 16.0 for Windows (SPSS Inc., Chicago, IL). Demographic and baseline characteristics were summarized as a mean \pm standard deviation for continuous variables and as a percentage of the group for categorical variables. Non-normally distributed data are presented as medians (interquartile range). The normality analysis was performed using the Kolmogorov-Smirnov test. Continuous variables were compared using the Mann-Whitney $U$ test because there were two groups and the data were not normally distributed. $\mathrm{P}<0.05$ was accepted as statistically significant.

\section{Results}

Twenty-eight patients with unilateral CAS (17 asymptomatic, 11 symptomatic) were included. The mean age of the asymptomatic CAS group was $66.53 \pm 7.8$ and the symptomatic CAS group was $57 \pm 10$ (Table 1$)$.

In the asymptomatic CAS group, 10 patients were male $(58.8 \%)$ and seven were female $(41.2 \%)$, and in the symptomatic group, seven were male $(63.6 \%)$ and four were female $(36.4 \%)$. Including all patients, the stenosis ratios were as follows: 10 patients had 50-70\%, 10 patients had $70-90 \%$, and eight patients had $\geq 90 \%$ stenosis. Hypertension was detected in 13 patients in the asymptomatic group and four in the symptomatic group. Three patients smoked in both the symptomatic and asymptomatic group. Patients with stroke with diabetes and patients with atrial fibrillation who might cause etiologic confusion were all excluded because the examined OCT parameters could be affected in diabetes mellitus. Demographic characteristics are shown in Table 1. There were no significant differences between the eye on the stenotic side and the fellow eye according to RNFLT, CMT, RGCL, and $\mathrm{CT}$ in the asymptomatic group $(\mathrm{p}=0.986, \mathrm{p}=0.945, \mathrm{p}=0.569$, 
and $\mathrm{p}=0.796$, respectively). Similarly, in the symptomatic group, no significant differences were found between the eye on the stenotic side and the fellow eye according to the same parameters $(\mathrm{p}=0.693, \mathrm{p}=0.409, \mathrm{p}=0.792$, and $\mathrm{p}=0.597$, respectively). When comparing the eyes on the stenotic sides in both groups, no significant differences were found $(\mathrm{p}=0.85, \mathrm{p}=0.24, \mathrm{p}=0.7$, $\mathrm{p}=0.98$, respectively) (Table 2 ).

\section{Discussion}

There were no significant differences between patients' eyes according to these parameters such as; RNFLT, CMT, RGCL and CT.

Several previous studies showed the relationship between plaque nature and OCT parameters. However, only a few studies are demonstrating the changes in the retina layer in patients with CAS who have asymptomatic eyes. In a previous study, a decrease in choroid thickness in both eyes was determined with 3-dimensional ultrasound in patients with hemodynamically significant bilateral ICA (10). In the study of Sayın et al. (11), a decrease in choroid thickness was observed in 25 patients with CAS when compared with controls; however, there were no significant differences between CAS rates and choroid thickness. Also, RNFLT, CMT, and RGCL values were similar in patient and control groups. In a study by Akçay et al. (12), patients with hemodynamically significant ICA stenosis who had $\geq 70 \%$ ICA diameter reduction showed a significant increase in choroid thickness in the eyes of the stenotic side and this situation was found to be related to the stenosis rate.

In Wang et al.'s (13) study, all of the participants were combined with amaurosis fugax and all of them had normal visual acuity and visual field. CT in eyes with severe ICA stenosis was lower than in the fellow eyes. However, no retinal structural changes occurred in eyes with severe ICA stenosis even though the posterior ciliary artery, a branch of the ophthalmic artery, supplies blood to the outer retina and choroid. According to the results, the authors concluded that choroidal thinning might occur before retinal changes in patients with ICA stenosis (13).

In our study, we included patients who had $\geq 50 \%$ unilateral ICA diameter reduction, and the patients were divided into two groups: Symptomatic CAS and asymptomatic CAS groups. However, there were no significant differences when comparing symptomatic CAS and asymptomatic CAS according to changes in the morphology of the retina.

In another study by Heßler et al. (14), the degree of carotid artery disease led to significant blood flow reduction in the central retinal artery, although similar to our findings, the flow reduction did not lead to morphologic or functional changes of the retina.

The severe stenosis of the extracranial segment of the ICA is the main cause of visual disturbances related to ocular ischemia (15). The most commonly experienced ischemic ocular symptom is transient mono ocular blindness, known as amaurosis fugax, which is caused by acute embolic central retinal artery occlusion (16). Chronic ipsilateral carotid stenosis might also cause OIS, with reported frequencies between $5 \%$ and $21 \%$. It is postulated that the underlying mechanism is decreased vascular perfusion resulting in tissue hypoxia and increased ocular ischemia, leading to neovascularization $(6,12,17,18)$. An embolus originating in the carotid artery is more likely to enter the ophthalmic artery (19), and may cause any of these four clinical conditions: (1) transient monocular visual loss, (2) central retinal artery occlusion, (3) central retinal artery branch occlusions, and (4) anterior ischemic optic neuropathy (6). However, we included patients with asymptomatic CAS in the chronic course and symptomatic CAS

Table 1. Demographic properties of both groups

\begin{tabular}{|lll} 
& Asymptomatic CAS group $(\mathbf{n}=17)$ & Symptomatic CAS group ( $=11)$ \\
Age (mean \pm SD) & $66.53 \pm 7.8$ & $57 \pm 10$ \\
Sex $(\%)$ & 7 females $(41.2 \%)$ & 4 females $(36.4 \%)$ \\
HT & 10 males $(58.8 \%)$ & 7 males $(63.6 \%)$ \\
Smoking & $13(76.5 \%)$ & $4(36.4 \%)$ \\
CAS: Carotid artery stenosis, HT: Hypertension, SD: Standard deviation & $3(27.3 \%)$ \\
\hline
\end{tabular}

Table 2. Optical coherence tomography parameters in carotid artery stenosis

\begin{tabular}{llll} 
& Asymptomatic & Symptomatic & p value \\
RNFL-affected & $90.6 \pm 11.0$ & $89 \pm 11$ & 0.85 \\
RNFL-normal & $89.5 \pm 14.7$ & $90 \pm 10.8$ & 0.54 \\
RGCL-affected & $77.6 \pm 12.9$ & $77.1 \pm 15.4$ & 0.70 \\
RGCL-normal & $73.5 \pm 16.8$ & $80.3 \pm 12.3$ & 0.72 \\
CMT-affected & $275 \pm 42$ & $254 \pm 45$ & 0.24 \\
CMT-normal & $271 \pm 57$ & $253 \pm 38$ & 0.82 \\
CT-affected & $285 \pm 101$ & $285 \pm 82$ & 0.98 \\
CT-normal & $281 \pm 98$ & $304 \pm 98$ & 0.79 \\
Affected: The eye on the stenotic side and normal: Fellow eye. RNFLT: Retinal nerve fiber layer thickness, CMT: Central macular thickness, RGCL: Retinal ganglion cell \\
\hline layer, CT: Choroidal thickness
\end{tabular}


in the acute phase; both groups had asymptomatic eyes. When comparing the side of the stenosis between asymptomatic and symptomatic groups, or comparing the stenotic side with the non-stenotic side, there were no significant differences concerning RNFLT, CMT, RGCL, and CT.

Previous experimental animal studies showed that retinal blood flow had not been significantly influenced by carotid artery ligation. This condition might be explained due to effective autoregulation of the retinal arteries in rabbits, cats, and monkeys $(20,21,22)$. The retinal blood vessels have no autonomic nervous supply, which implies that retinal blood flow is auto-regulated and the retinal blood flow may be sustained by collateral circulation in chronic stenotic conditions (23). Different systemic conditions may affect the $\mathrm{CT}$, one of them is supposed to be hypercholesterolemia due to the choroid's susceptibility to atherosclerotic changes (24). Age, sex, refractive error, and increased intraocular pressure may also affect CT $(13,25,26,27)$. Various imaging techniques have been used to evaluate patients with CAS; however, a novel technique that provides high-resolution images of the retinal vasculature as measured using OCT angiography (OCT-A) could be useful in the diagnosis of CAS and evaluation of therapy success (28). Another prospective study could be designed to show more certain results.

\section{Study Limitations}

We acknowledge the limitations of including a small group of subjects in the study, though the sample size was similar to other studies. However, in contrast with other studies, the patients were divided into two groups: Patients with symptomatic CAS and asymptomatic CAS. Even though patients with long-term hypertension were excluded, patients had an increased hypertension rate. So as not to administer unethical contrast injections to healthy subjects with CTA, healthy subjects could not be included in the study as a control group, although our control group did have similar risk factors to the patient groups. Although stenosis was detected with CTA in patients with CAS, intracranial artery flow rate or retinal vasculature were not measured using transcranial magnetic stimulation or OCT-A. Therefore, it has not been demonstrated whether the degree of stenosis hemodynamically affects the retinal artery.

\section{Conclusion}

In this prospective study, the decrease in retinal artery blood flow did not lead to morphologic or functional changes of the retina in symptomatic or asymptomatic carotid artery disease. Further studies in a larger population are needed to present more certain results for evaluating the retinal changes in embolic stroke or recent carotid artery disease.

\section{Ethics}

Ethics Committee Approval: The study was approved by the Antalya Training and Research Hospital Ethics Committee (48/2, 16.10.2014).

Informed Consent: Written informed consent was received from all participants.

Peer-review: Externally peer-reviewed.

\section{Authorship Contributions}

Surgical and Medical Practices: E.Ö.G., B.D., A.C.Ü., Concept: E.Ö.G., B.Y., Design: E.Ö.G., B.D., A.C.Ü., Data
Collection or Processing: E.Ö.G., Analysis or Interpretation: E.Ö.G., B.Y., Literature Search: E.Ö.G., B.Y., Writing: E.Ö.G., B.Y.

Conflict of Interest: The authors have not declared any conflict of interest related to this article.

Financial Disclosure: No financial support was received from any institution or person for our study.

\section{References}

1. Feigin VL, Krishnamurthi RV, Parmar P, et al. Update on the Global Burden of Ischemic and hemorrhagic stroke in 1990-2013: The GBD 2013 study. Neuroepidemiology 2015;45:161-176.

2. Marsh JD, Keyrouz SG. Stroke prevention and treatment. J Am Coll Cardiol 2010;56:683-691.

3. Gupta A, Chazen JL, Hartman M, et al. Cerebrovascular reserve and stroke risk in patients with carotid stenosis or occlusion: a systematic review and meta-analysis. Stroke 2012;43:2884-2891.

4. Göksu EÖ, Koç P, Küçükseymen E, et al. The association of the circle of Willis anomaly and risk of stroke in patients with carotid artery disease. Arq Neuropsiquiatr 2017;75:429-432.

5. Romero JR, Pikula A, Nguyen TN, et al. Cerebral collateral circulation in carotid artery disease. Curr Cardiol Rev 2009;5:279-288.

6. Arthur A, Alexander A, Bal S, Sivadasan A, Aaron S. Ophthalmic masquerades of the atherosclerotic carotids. Indian J Ophthalmol 2014;62:472-476.

7. Kumar V, Cotran RS, Robbins SL. Basic pathology. 15th ed. Philadelphia: W.B Saunders, 1992;3-24.

8. Stevens WD, Fortin T, Pappas BA. Retinal and optic nerve degeSneration after chronic carotid ligation: time course and role of light exposure. Stroke 2002;33:1107-1112.

9. Huang D, Swanson EA, Lin CP, et al. Optical coherence tomography. Science 1991;254:1178-1181.

10. Ivashina AI, Ioffe DI, Zolotarevskii AV, Mikhailova GD, Kuntsevich GI Dynamics of changes in the thickness of the choroid in patients with stenosis of the internal carotid artery. Vestn Oftalmol 1989;105:65-67.

11. Sayın N, Kara N, Uzun F, Akturk IF. A Quantitative evaluation of the posterior segment of the eye using spectral-domain optical coherence tomography in carotid artery stenosis: a pilot study. Ophthalmic Surg Lasers Imaging Retina 2015;46:180-185.

12. Akçay BİS, Kardeş E, Maçin S, et al. Evaluation of subfoveal choroidal thickness in internal carotid artery stenosis. J Ophthalmol 2016;2016:5296048.

13. Wang H, Wang YL, Li HY. Subfoveal choroidal thickness and volume in severe internal carotid artery stenosis patients. Int J Ophthalmol 2017;10:1870-1876.

14. Heßler H, Zimmermann H, Oberwahrenbrock T, et al. No evidence for retinal damage evolving from reduced retinal blood flow in carotid artery disease. Biomed Res Int 2015;2015:604028.

15. Mizener JB, Podhajsky P, Hayreh SS. Ocular ischemic syndrome. Ophthalmology 1997;104:859-864.

16. Dugan Jr JD, Green WR. Ophthalmologic manifestations of carotid occlusive disease. Eye (Lond) 1991;5:226-238.

17. Kearns TP, Siekert RG, Sundt Jr TM. The ocular aspects of bypass surgery of the carotid artery. Mayo Clin Proc 1979;54:3-11.

18. Kersemakers P, Beintema M, Lodder J. Venous stais retinopathy unlikely results from internal carotid artery obstruction alone. Cerebrovasc Dis 1992;2:305-307.

19. Chung SE, Kang SW, Lee JH, Kim YT. Choroidal thickness in polypoidal choroidal vasculopathy and exudative age-related macular degeneration. Ophthalmology 2011;118:840-845.

20. Bill A. Effects of acetozolamide and carotid acclusion on the ocular blood flow in unanesthetized rabbits. Invest Ophthalmol 1974;13:954-958.

21. Alm A, Bill A. The oxygen supply to the retina. II. Effects of high intraocular pressure and of increased arterial carbon dioxidetension on uveal and retinal blood flow in cats. A study with radioactively labelled microspheres including flow determinations in brain and some other tissues. Actha Physiol Scand 1972;84:306-319.

22. Alm A, Bill A. Ocular and optic nerve blood flow at normal and increased intraocular pressures in monkeys (Macaca irus):a study with radioactively 
labelled microspheres including flow determinations in brain and some other tissues. Exp Eye Res 1973;15:15-29.

23. Laties AM. Central retinal artery innervation. Absence of adrener- gic innervation to the intraocular branches. Arch Ophthalmol 1967;77:405409.

24. Wong IY, Wong RL, Zhao P, Lai WW. Choroidal thickness in relation to hypercholesterolemia on enhanced depth imaging optical coherence tomography. Retina 2013;33:423-428.

25. Kim KH, Kim DG. The relationship among refractive power, axial length and choroidal thickness measured by SD-OCT in myopia. J Korean Ophthalmol Soc 2012;53:626.
26. Ikuno Y, Kawaguchi K, Nouchi T, Yasuno Y. Choroidal thickness in healthy Japanese subjects. Invest Ophthalmol Vis Sci 2010;51:2173-2176.

27. Li XQ, Larsen M, Munch IC. Subfoveal choroidal thickness in relation to sex and axial length in 93 Danish university students. Invest Ophthalmol Vis Sci 2011;52:8438-8441.

28. Lahme L, Marchiori E, Panuccio G, et al. Changes in retinal flow density measured by optical coherence tomography angiography in patients with carotid artery stenosis after carotid endarterectomy. Sci Rep 2018;8:17161. 